Cinémas

Revue d'études cinématographiques

Journal of Film Studies

\title{
"Common People with Common Feelings:" Pauline Kael, James Agee, and the Public Sphere of Popular Film Criticism
}

\section{Leo Charney}

Volume 6, numéro 2-3, printemps 1996

La Critique cinématographique

URI : https://id.erudit.org/iderudit/1000975ar

DOI : https://doi.org/10.7202/1000975ar

Aller au sommaire du numéro

Éditeur(s)

Cinémas

ISSN

1181-6945 (imprimé)

1705-6500 (numérique)

Découvrir la revue

Citer cet article

Charney, L. (1996). "Common People with Common Feelings:" Pauline Kael, James Agee, and the Public Sphere of Popular Film Criticism. Cinémas, 6(2-3), 113-126. https://doi.org/10.7202/1000975ar
Résumé de l'article

Cet article traite des écritures de Pauline Kael et James Agee comme exemples conducteurs de la rhétorique de la critique du film populaire états-unien, caractérisées par trois éléments : l'effort pour se distancier des autres critiques et de l'industrie du spectacle; la volonté de mettre l'accent sur la nature personnelle et subjective de leur perception de chacun des films; et l'utilisation de l'écriture comme catalyseur pour une sphère publique de réaction au film. 


\title{
"Common People with Common Feelings:" Pauline Kael, James Agee, and the Public Sphere of Popular Film Criticism
}

\section{Leo Charney}

\begin{abstract}
RÉSUMÉ
Cet article traite des écritures de Pauline Kael et James Agee comme exemples conducteurs de la rhétorique de la critique du film populaire états-unien, caractérisées par trois éléments: l'effort pour se distancier des autres critiques et de l'industrie du spectacle; la volonté de mettre l'accent sur la nature personnelle et subjective de leur perception de chacun des films; et l'utilisation de l'écriture comme catalyseur pour une sphère publique de réaction au film.
\end{abstract}

\section{ABSTRACT}

This essay focuses on the writings of Pauline Kael and James Agee as the leading examples of the rhetoric of American popular film criticism, which the author suggests is characterized by three elements : the critic's effort to distance him / herself from both other critics and the entertainment industry; to emphasize the personal and subjective nature of his / her responses; and to use his / her writing as the catalyst for a public sphere of film response.

The rhetoric of American popular film criticism arises on the shifting sands between authority and persuasion. In contrast to the scholarly discourse of academic film criticism and the reportorial tone of newspaper film reviewing, popular film critics 
strategically emphasize the personal nature of their responses. Yet they must also reach beyond this subjectivity to persuade readers, support evaluative authority, and catalyze communal response. The critic is one viewer who expresses one opinion, yet film critics aspire to resolve this potentially troubling crisis of authority by foregrounding rather than concealing it. By presenting himself as one of the "common people with common feelings," in Pauline Kael's phrase, who watches movies in the real world, the critic hopes to enhance her powers of persuasion, to deploy her painstakingly constructed normality as the catalyst for an interpretive community of film-goers.

The ranks of twentieth-century American film critics have included such writers as Manny Farber, Stanley Kauffmann, Dwight Macdonald, and Andrew Sarris. My brief analysis focuses on the work of arguably the two most important and influential of these figures, James Agee and Pauline Kael. While Agee and Kael both elaborate a distinctive style and taste, they also both manifest popular film criticism's three characteristic traits: the critic distances himself from both other critics and the entertainment industry, depicting himself as independent, disinterested, and trustworthy; emphasizes the personal, subjective nature of her responses as one of the "common people with common feelings" who watches movies; and then uses this subjectivity to license a shift from personal to communal response, a shift that converts the critic's subjective opinion into the engine of communal persuasion and the focal point of a public sphere of film response.

The academic film essay generally begins by placing itself inside a pre-established community of scholarly work. "The standard opening" of the academic essay, as David Bordwell has noted, " $[\ldots]$ ritualistically positions this essay with respect to established or up-and-coming work, sometimes by a quick review of the current literature." (p. 219) This rhetorical communityformation is reenforced by jargon, which locates the academic article inside its interpretive community: jargon, as Bordwell puts it, " $[\ldots]$ serves to close the ranks, shutting out the uninitiated and reinforcing communal solidarity." (p. 217) The popular film critic, on the other hand, makes every effort to disasso- 
ciate himself from other critics. "Sometimes, when I read film critics," as Pauline Kael put it, "I think I can do without brothers." At the same time, the critic also takes pains to distance herself from the entertainment industry. "In short," wrote Dwight Macdonald of Ben-Hur, "here is a film that tries to debauch whatever taste, feeling or simple common sense Hollywood and television have left us." (p. 426) ' Pauline Kael hyperbolically characterized this position when she responded to a truculent radio listener :

Well, what makes a "name" movie is simply a satura-
tion advertising campaign, the same kind of campaign
that puts samples of liquid detergents at your door.
The "name" pictures of Hollywood are made the same
way they are sold : by pretesting the various ingre-
dients, removing all possible elements that might af-
front the mass audience, adding all possible elements
that will titillate the largest number of people. (1994,
p. 53)

Setting himself apart from the culture industry, the film critic positions himself in league with his reader. "As a member of the audience," wrote Kael of One, Two, Three, "I felt degraded and disgusted, as if the dirt were being hurled right in my face." (1965, p. 136) The critic presents herself as a lone rider, a guardian of taste. Detached from any context other than herself, the critic can then use her subjectivity as the pivot of persuasion.

The strategic depiction of the critic as an average movie-goer was exemplified in the work of James Agee, whose self-effacing style emerged most clearly in his reviews for The Nation in the Forties, where he was less constrained by length and house style than in his reviews for Time in the same period. Like Kael, Agee enjoyed setting himself against other critics. "Having written what seems to me a fair review, if only in the subjunctive," he wrote of The Notorious Gentleman, ${ }^{2}$

perhaps I ought to let it go at that. But I can't. Most of the people I know who have seen the film in preview think so well of it that I am all but sure it will get a reputation it doesn't deserve. Although, as is perhaps immodest to point out, the whole of the movie world

“Common People with Common Feelings:" Pauline Kael, James Agee... 
waits trembling from fortnight to fortnight to learn from this column what should or should not be done next, I am afraid I can't prevent the development of this false reputation; that will occur mainly among intellectuals. But at least I can throw spitballs. (p. 219)

Agee disagreed with other critics as a strategy to disavow his own authority. They are the "intellectuals," the ones who determine public taste, while he is a regular guy throwing spitballs. He bends over backwards to deprecate the notion that he might possess any authority of any kind. "If Shakespeare," he began a sentence in his review of Henry $V$, "had been no more gifted with words than, say, I am..." Agee carefully maintained this persona through his mastery of syntax, above all the emphasis on "I" and such colloquial contractions as "can't." To bolster the effect of subjectivity, Agee often placed his lone voice against those of others: "The press," he wrote as if it were separate from him, "on [...] Henry $V$ has been exceptionally warm and friendly, as seems no more than proper. Although the press is not to blame for it there is also a rumor, credited apparently by a good many, that it is the best movie ever made." Agee sets himself apart not just from "the press" but also from the "good many" who are... who? Defining himself against this anonymous group, he enforces his stance as both an outsider and an authority, a voice of judgment not indebted to fickle rumor.

Having placed himself rhetorically as just another guy, Agee goes on to distinguish himself subtly from other members of the mass audience, enforcing his own authority as the critic. "I finally caught up with The Dark Corner - not, I must confess, so badly out of breath as duty tells me I should have been. I enjoyed seeing it. I think everyone was right who pointed out that it is a shameless combination of formulas [...]." In this passage, Agee's rhetoric emphasizes his first-person, subjective voice: "I enjoyed seeing it." But this persona is set against both "everyone," whose opinion Agee judges, and his role as critic, a "duty" that Agee separates from the "I" who enjoys movies. "Frankly," he wrote elsewhere,

I doubt I am qualified to arrive at any sensible assessment of Miss Elizabeth Taylor. Ever since I first saw the 
child, two or three years ago, in I forget what minor role in what movie, I have been choked with the peculiar sort of adoration I might have felt if we were both in the same grade of primary school. I feel I am obligated to this unpleasant unveiling because it is now my duty to try to review her, in National Velvet, in her first major role.

Agee places himself outside the community of other critics to locate himself instead in the non-specialist community of filmgoers. His style, which might seem solipsistically personal, in fact gestures outward toward the community of readers that surrounds it. Within this community, the critic's opinion gets cast as personal preference: "Of the movies I have seen lately the one I like best was To Have and Have Not"; "It Happened in Brooklyn features Frank Sinatra, whom I like"; "Children of Paradise [...] is close to perfection of its kind and I very much like its kind." The critic's authoritative opinion becomes one viewer's personal reaction to one film and thereby authorizes the parallel opinions of other film viewers in this external community. I just happen to have gotten this job as a film reviewer, Agee's rhetoric strives to remind us. Other than by having this job, my reactions are no different from yours. The rhapsody on Elizabeth Taylor epitomizes this self-conscious split between experience and authority.

The early work of Pauline Kael took Agee's highly personal style one step further, not simply deploying a rhetoric of subjectivity but explicitly privileging subjective response over "objective" standards, which for Kael emblematized the dual manipulations of both other critics and the culture industry. "I'm not sure most movie reviewers consider what they honestly enjoy as being central to criticism," she wrote in her manifesto, "Trash, Art, and the Movies."

Some at least appear to think that that would be relying too much on their own tastes, being too personal instead of being "objective" — relying on the readymade terms of cultural respectability and consensus judgement (which, to a rather shocking degree, can be arranged by publicists creating a climate of importance around a movie). (1994, p. 214) 
Kael portrays authority and objectivity as gestures of power, designed to make regular movie-goers feel bad about the validity of their instinctive responses; personal response is all that exists, while critical "objectivity" constructs a scaffolding to justify subjective reactions and bolster the critic's authority at the expense of the viewer's response. This stance marks not a random set of evaluative reactions but a rigorously held theoretical polemic:

There are not - and there never were - any formal principles that can be used to judge movies but there are concepts that are serviceable for a while and so pass for, or are mistaken for, "objective" rules until it becomes obvious that the new work that we respond to violates them. (Kael, 1994, p. 103)

Valorizing subjective response becomes, for Kael, an antiauthoritarian gesture, an act of empowerment. Above all in "Trash, Art, and the Movies," she defined "art" as a category of manipulation, a con designed by critics and press agents to keep themselves in power at the expense of movie viewers: it is "preposterous," she writes,

to let prestigious, expensive advertising snow us into thinking we're getting art for our money when we haven't even had a good time. [...] if a movie is said to be a work of art and you don't enjoy it, the fault may be in you, but it's probably in the movie. [...] In American movies what is most often mistaken for artistic quality is box-office success, especially if it's combined with a genuflection to importance [...]. (1994, p. 213)

In Kael's aesthetic, personal experience forms the basis and the ground for critical evaluation. "This is the West I and so many of my friends came out of," she wrote in her review of $H u d$, "escaping from the swaggering small-town hotshots like Hud. But I don't remember any boys like Brandon de Wilde's Lon: he wasn't born in the West or in anybody's imagination; that seventeen-year-old blank sheet of paper has been handed down from generations of lazy hack writers." (1994, p. 6) This endeavor would seem to open the door to solipsism, but Kael 
always emphasized the link between personal experience and communal experience as the foundation of movie-going. "Part of the fun of movies," she wrote in "Trash, Art, and the Movies,"

is in seeing "what everybody's talking about," and if people are flocking to a movie, or if the press can con us into thinking that they are, then ironically, there is a sense in which we want to see it, even if we suspect we won't enjoy it, because we want to know what's going on. [...] An analyst tells me that when his patients are not talking about their personal hangups and their immediate problems they talk about the situations and characters in movies [...] and they talk about them with as much personal involvement as about their immediate problems. (1994, p. 224)

Film, in Kael's vision, forms an inter-subjective, experiential link among friends, lovers, and strangers. "Our experience as we watch it, she wrote of Bonnie and Clyde, has some connection to the way we reacted to movies in childhood: with how we came to love them and to feel they were ours - not an art that we learned over the years to appreciate but simply and immediately ours." (1994, p. 141) "People go to the movies," she later suggested, "for the various ways they express the experiences of our lives." Kael related this experience through narrating her own experience of movies, which she defined as both continuous with the personal experiences that enmesh it and inseparable from the standards of value with which one evaluates that film experience. "When Shoeshine opened in 1947," she wrote in a famous passage,

I went to see it alone after one of those terrible lovers' quarrels that leave one in a state of incomprehensible despair. I came out of the theater, tears streaming, and overheard the petulant voice of a college girl complaining to her boyfriend, "Well, I don't see what was so special about that movie." I walked up the street, crying blindly, no longer certain whether my tears were for the tragedy on the screen, the hopelessness I felt for myself, or the alienation I felt for those who could not experience the radiance of Shoeshine. For if people cannot feel Shoeshine, what can they feel? (1994, p. 16) 


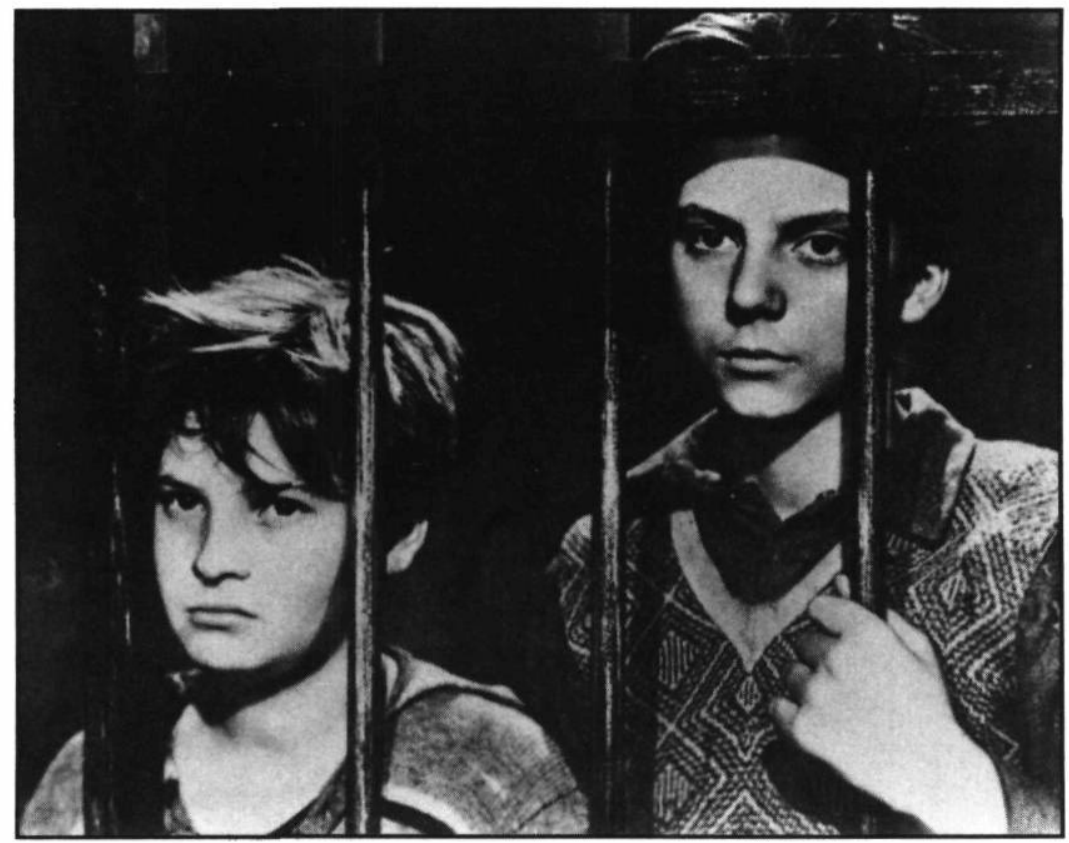

Shoeshine, Vittorio de Sica (1946)

The "I" who began the passage on such a personal note winds up as the leader of a community of those who "experience the radiance of Shoeshine." The response becomes more than just subjective in its concomitant appeal to intersubjective, communal experience. Film experience involves participating in a larger community of film-goers, a social network or public sphere that yokes together disparate strangers through their common experience of movies. "The romance of movies," Kael wrote in the opening sentence of "Trash, Art, and the Movies," "is not just in those stories and those people on the screen but in the adolescent dream of meeting others who feel as you do about what you've seen."

One of Kael's most straightforward statements of her critical principles came in the four-paragraph Author's Note that opened her 1973 collection Deeper Into Movies:

I try to use my initial responses (which I think are probably my deepest and most honest ones) to explore 
not only what a movie means to me, but what it may mean to others; to get at the many ways in which movies, by affecting us on sensual and primitive levels, are a supremely pleasurable — and dangerous - art form.

(1973, p. xvii-xviii)

Kael here delineated the progression that defined both her criticism and the method of popular film criticism in general. First she responds intuitively and subjectively to the film, which, as in traditional models of the sublime, evokes both pleasure and danger. Then she tries to link her responses to a wider community of others who share her values. Response is first subjective, then inter-subjective; and Kael's criticism always places itself inside an implicit interpretive community that shares certain values and assumptions. " ${ }^{3}$ "I don't trust anyone who doesn't admit having at some time in his life enjoyed trashy American movies," she acknowledged in "Trash, Art, and the Movies." "The educated person who became interested in cinema as an art form through Bergman or Fellini or Resnais is an alien to me," she wrote elsewhere, " (and my mind goes blank with hostility and indifference when he begins to talk)." (1994, p. 123-124)

Kael thus writes from the midst of grappling with her response, struggling with it, working it out, putting it across. "I write," she continued in the Deeper Into Movies Author's Note, "because I love trying to figure out what I feel and what I think about what I feel, and why." She positions herself not as the schoolmarm who will instruct us in how to appreciate art, but as a person who responds to movies. "We're not only educated people of taste," she wrote, "we're also common people with common feelings. And our common feelings are not all "bad'." (1994, p. 218) This sort of statement addressed for Kael the most vexing rhetorical problem of writing criticism: how to maintain the critic's authority while also appealing to the reader to sustain your ability to persuade.

In this light, the lack of consistent critical standards for which Kael has often been criticized ${ }^{4}$ seems not the accidental blunder that her critics portray but a calculated rhetorical effort to locate herself inside a public sphere of response. Placing herself against

“Common People with Common Feelings:" Pauline Kael, James Agee... 
the Hollywood industry but also against art cinema; against other critics; and refusing to judge films by an invariably applied "standard," Kael emphasized response. She enforced her own authority by placing herself outside the sphere of those authorities she circularly defined as manipulative and untrustworthy. She gets readers to trust her by positioning herself as the only person they can trust. This emphasis both allies her with and aims to articulate a public sphere of film response.

The emphasis on "common feelings" sets itself against not just intellectualized art cinema but also authority in general. "The movies we respond to, even in childhood," Kael proposed in "Trash, Art, and the Movies,"

don't have the same values as the official culture supported at school and in the middle-class home. At the movies we get low life and high life, while David Susskind and the moralistic reviewers chastise us for not patronizing what they think we should [...] Movie art is not the opposite of what we have always enjoyed in movies, it is not to be found in a return to that official high culture, it is what we have always found good in movies only more so. (1994, p. 209-212)

In such passages, Kael posed a public sphere of response that orients itself against the effort of authorities and high culture to rein it in or give it direction. In the thorny issue of how meaning and value arise, Kael wants to shift the burden to communal experience. This experience links film to culture through experience, and through the commonality of that experience. This tactic is of course disingenuous, since the critic is not, as Agee always tries to make him, just another film-viewer. This problem of authority ushers in persuasion as criticism's necessary third stage. Having placed herself inside a community of filmgoers, but also possessing more rhetorical authority than those communal peers, the critic reconciles these positions through the effort toward persuasion, which turns authority outward toward communal consensus.

The critic's persuasion relies on a three-way progression from opinion to community to persuasion; opinion sets in motion community, and they meet on the ground of persuasion. "The 
art of the critic," in Kael's formulation, "is to transmit his knowledge of and enthusiasm for art to others." The critic begins with "knowledge" and "enthusiasm" and then wants to find "others" to whom she can "transmit" those feelings. First the critic must hold a personal, deeply felt, subjective reaction to a film; opinion is the motor of persuasion. "For the past year on the radio," Kael averred, "I had tried to persuade, goad, and even shame people into seeing L'Avventura, which I think is a great film." (1965, p. 161) This imperative of persuasion impels critics to divorce themselves from authority: presenting himself as a regular person seeing movies just like you, the critic lays the rhetorical ground for persuasion. Detached from the institutional props of either the film industry or other critics, the critic reaches out to his fellow film-goers in a community of film experience.

In this sense, Kael wants to claim for the film community a form of public sphere, articulated around film as Jürgen Habermas suggested that an eighteenth-century public sphere arose around journalism. "The press," proposed Habermas, "remained an institution of the public itself, effective in the manner of a mediator and intensifier of public discussion." (p. 53) The public sphere, Habermas emphasized, implied not agreement or unanimity but a site where people could meet, argue, and hash out their competing views. Nothing is more important to Kael than maintaining this freedom of the public sphere, and this crusade grounds her distaste toward both intellectuals and the culture industry. "When movies," she wrote,

the only art which everyone felt free to enjoy and have opinions about, $[\ldots]$ become cinema, which people fear to criticize just as they fear to say what they think of a new piece of music or a new poem or painting, they will become another object of academic study and "appreciation," and will soon be an object of excitement only to practitioners of the "art." (1965, p. 21)

Kael cast this attack on the academicization of film as a Habermasian fear of the dimunition of film's appeal to a public sphere " $[\ldots]$ which everyone felt free to enjoy and have opinions about," a turn of phrase almost identical to Habermas' 
mordant reflections on journalism's corruption by commerce. As in Habermas' utopian vision of journalism, film becomes a pivot of communal experience. But while Habermas utopically assumed that all conflicts can be civilly worked out through impersonal mediation, popular film criticism retains a distinction between the general community of film-goers and the specific community drawn around one critic's criticism. On the broadest plane, film becomes a vehicle of "our" communal experience. Yet the community invoked in one critic's writing is not this pluralistic "we" but a community of readers invited to share the critic's tastes and values, formed by personal experiences, expressed through the subjectivity of prose. "Why are you listening to a minority radio station like KPFA?" Kael belligerently asked one of her San Francisco radio listeners. "Isn't it because you want something you don't get on commercial radio? I try to direct you to films that, if you search them out, will give you something you won't get from The Parent Trap." (1994, p. 53) As Kael's nemesis Renata Adler wrote about her own film criticism for The New York Times, "The readers I guess I was writing for, and whom I presumed I had been hired for, were people fairly like myself, or specific friends I had had somewhere along the way. It varied a bit, depending on whom I had seen or lately read. I don't think it is possible to write for people completely unlike yourself." (Adler, p. xxii)

Popular film criticism in these ways catalyzes not just a generalized public sphere but more specifically a post-Habermas model of smaller public spheres, formed as interpretive communities around certain values, certain films, certain forms of taste, style, ideology, and ethnic, class, or other modes of identification. ${ }^{5}$ As Miriam Hansen has noted in the foreword to Oskar Negt and Alexander Kluge's Public Sphere and Experience, "Once the public sphere is defined as a horizon for the organization of social experience, it follows that there are multiple and competing counterpublics, each marked by specific terms of exclusion [...] yet each understanding itself as a nucleus for an alternative organization of society." (Negt and Kluge, p. xxxvi) While popular film criticism may not directly engage sociopolitical realms, it forms part of this ongoing twentieth-century 
re-articulation of the public sphere as, in the words of Hansen after Negt and Kluge,

(1) an unstable mixture of different types of publicity [... ; (2) a site of discursive contestation for and among multiple, diverse, and unequal constituencies; (3) a potentially unpredictable process due to overlaps and conjunctures between different types of publicity and diverse publics $[\ldots]$. (p. xxix)

Popular film criticism sets out these elements of the public sphere not just as content but as form and rhetoric. The authority (in both senses of the word) of popular film criticism brings into the open the markers of taste and subjectivity that may remain more craftily concealed in other forms of critical discourse. By definition, popular film critics place value on the table as a site for negotiation and challenge. Through the vehicle of the critic, individual experience meets communal experience at the juncture of taste and subjectivity; and the public sphere of popular film criticism in this way provides a potential meeting ground for maneuver and contestation among the critic, the reader, the film industry, the critical industry, and the wider community of film-goers - all of whom popular film criticism aspires to bring together as a movie-going public of "common people with common feelings."

University of Iowa

\section{NOTES}

1 For Macdonald's hostility toward the entertainment industry, see most famously "Masscult and Midcult," Against the American Grain (New York: Random House, 1962).

2 All citations of Agee are to this volume.

3 The concept of the interpretive community derives from Stanley Fish, Is There a Text in This Class? The Authority of Interpretive Communities (Cambridge: Harvard University Press, 1980).

4 Most famously in Renata Adler, "The Perils of Pauline," New York Review of Books, 14 August 1980.

5 This is the point at which the study of popular film criticism would intersect with the work of Pierre Bourdieu in Distinction: A Social Critique of the Judgement of Taste (Cambridge : Harvard University Press, 1984).

“Common People with Common Feelings : " Pauline Kael, James Agee... 


\section{WORKS CITED}

Adler, Renata. A Year in the Dark. New York: Random House, 1969.

Agee, James. Agee on Film. New York: Perigee, 1958.

Bordwell, David. Making Meaning. Inference and Rhetoric in the Interpretation of Cinema. Cambridge: Harvard University Press, 1989.

Habermas, Jürgen. "Public Sphere». New German Critique, n” 3 (1974).

Kael, Pauline. For Keeps: Thirty Years at the Movies. New York: Dutton, 1994.

Kael, Pauline. Deeper into Movies. New York: Warner, 1973.

Kael, Pauline. I Lost It at the Movies. Boston: Little Brown, 1965.

Macdonald, Dwight. On Movies. New York: Da Capo, 1981.

Negt, Oskar and Alexander Kluge. Public Sphere and Experience. Minneapolis: Minnesota University Press, 1993. 